\title{
Rediscovering Islamic Science
}

\begin{abstract}
An exhibition of Islamic Science opens this week in Londonone of many displays, concerts and meetings organised by the Festival of Islam to give a perspective on the Islamic world. David Davies reports
\end{abstract}

IT is very easy to view the historical development of science in terms of the contributions that separate nations or civilisations have made to what we now regard as real, successful, all-encompassing Western science. We get decimals from one place, the lodestone from another, paper from a third and so on. But knowing the history of science only in terms of what we got out of where is like knowing world geography only in terms of what different countries export-a common feature, it used to seem, of school textbooks. in order to understand Islamic science properly, one has to try and identify with Islamic needs and beliefs, and if one is thereby led into alchemy and astrology as well as water-engineering and mathematics, this was no less science in the Islamic world. "We have tried," say Francis Maddison and Anthony Turner in the introduction to their catalogue of the exhibition, "in all modesty, and albeit imperfectly as nonMuslims, to picture Islamic science and technology from within, that is, as part of the intellectual and everyday life of a widely heterogeneous community founded on a common faith."

Wide indeed; the Islam world stretches from Spain to Indonesia, from Samarkand to central Africa. And in time the exhibition, at London's Science Museum, covers nearly a millennium from the first infusion of Hellenic knowledge in the eighth century to the fading away of a specifically Islamic science in the sixteenth and seventeenth centuries. The word science in the exhibition does not, of course, have its present professional connotations of making hypotheses, verifying or falsifying them. It is much more the science-museum/popular view of science as a body of knowledge about things. As far as we know, the doing of experiments in a systematic way was as unknown in the Islam world of the middle ages as it was in the western world of the same period.

Two things cemented the Islam world: the dominance of two main languages, Arabic and Persian, and the importance of religion in everyday life.

The exhibition at the Science Museum is open daily until August 29. Admission $30 p$; children, students and pensioners $15 p$.
From religious needs sprang much of the science that will be on show. The great eleventh century philosopher alBiruni commented rather tartly that people were paying more attention to their food, which was a twice-daily concern, than to their prayers, which occurred five times a day. It was in the correct ordering of these prayers that science had a major part to play, both in the accurate measurement of time and in determination of the direction of Mecca so that the prayer mat should be correctly aligned. Thus flourished clocks, sandglasses, astrolabes, astronomical tables, spherical trigonometry and so on. But at the same time there is astrology which was, at a later date in Western science, practised by some but which scandalised others.

The Islamic world stretched east to Indonesia but there is little evidence remaining beyond India of scientific ฆ achievements. But Muslims were great travellers, and Egypt and Syria in particular managed at the crossroads to hear about everything.

The exhibition has posed particular problems of what to display. To the scholar the most important sources are the manuscripts, of which there are large numbers. But in planning the exhibition Maddison and Turner have had to keep manuscripts to a minimum simply because they would be generally incomprehensible to a London public. Astrolabes were relatively easy to accumulate for most periods, but the difficulty has been in putting together a representative sample of other objects to exemplify the extent of knowledge. It has turned out that the richest sources of exhibits have been Paris, London and Oxford museums, rather than the Islamic countries themselves. A major disappointment, however, has been that Turkish law forbids even the temporary export of materials from particularly fine collections.

Prosperity in the Islamic world was largely determined by the availability of water, and so the exhibition has had to take note of water technology. But some of the most fascinating examples only existed in manuscript formnotably in al-Jazari's thirteenth century Book of Knowledge of Ingenious Mechanical Devices. No one, as far as is known, has constructed any of these devices for seven hundred years, but the recent publication of Donald Hill's

\section{Sorry, for copyright reasons some images on this page may not be available online}

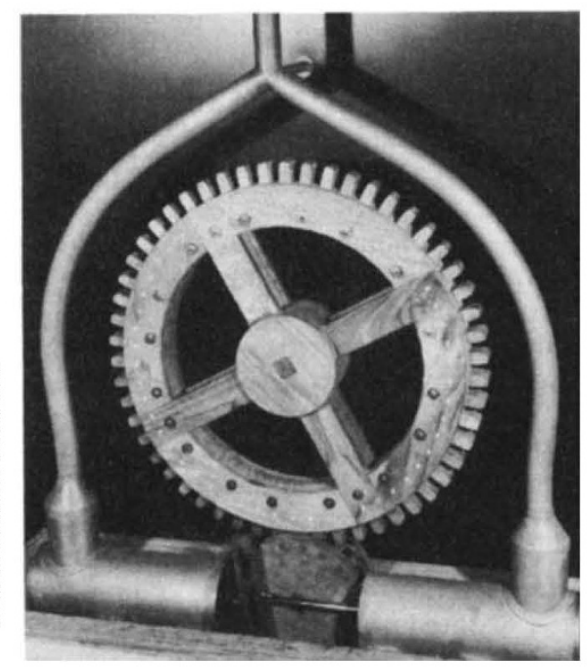

Modern alchemist's still (above) and (below) the model of a water pump driven by a water wheel

splendid translation (Reidel, 1973) has awakened a wide interest in them. A huge water-clock built specially for the exhibition according to al-Jazari's specifications will undoubtedly be the central attraction for most people. Equally noteworthy, however, will be the half-size model of a water pump driven by a water wheel, also described by al-Jazari. The original was the first recorded pump to be powered other than by human or animal-power.

It is difficult to date the decline of a specifically Islamic science. The growth of the Ottoman Empire in Turkey helped to extend the period, and, both through Turkey and Spain, aspects of Islamic science were siphoned into Western civilisation.

There seems little doubt that the Islamic exhibits being brought together in London, not only of science, but of art, architecture, musical instruments and books, represent a unique occasion. And few believe there will ever in the foreseeable future be another occasion on which so much of the Islamic world can be seen in one city. 